\title{
Arizona hinshawii bacteraemia and meningitis in a child: a case report
}

\author{
REBECCA ICHORD, ITZHAK BROOK, AND GUIDO CONTRONI \\ From the Department of Infectious Diseases and the Clinical Microbiology Laboratories, \\ Children's Hospital National Medical Center and George Washington University School of Medicine, \\ Washington, DC, USA
}

SUMmARY An 8-week-old infant presented with Arizona hinshawii meningitis and bacteraemia. The child responded well to the administration of parenteral ampicillin and chloramphenicol. However, chloramphenicol was discontinued after one day of therapy, and $A$. hinshawii was recultured from the cerebrospinal fluid on the fifth day. Chloramphenicol therapy was restarted and the patient had an uneventful recovery. This report is the first description of $A$. hinshawii meningitis and should alert clinicians to the possible occurrence of this infection in endemic areas.

Arizona hinshawii has been described as a rare cause of disease in humans. ${ }^{1}$ Its spectrum resembles closely that of Salmonella species. Although salmonella meningitis has been reported, ${ }^{2}$ Arizona species have not previously been known to cause meningitis. In this report we describe a case of meningitis due to $A$. hinshawii with particular reference to host factors, clinical course, and the organism's antibiotic sensitivities.

\section{Case report}

An 8-week-old white girl was admitted to hospital because of a 24-hour history of high fever, vomiting, progressive lethargy, and one generalised tonic seizure. She was the normal $3.3 \mathrm{~kg}$ product of fullterm uncomplicted pregnancy, labour, and delivery. She lived in Saipan, Micronesia, with her family and was well until 6.5 weeks of age when she had a brief febrile gastroenteritis with several bloody stools which resolved on clear fluids alone. She remained well until 8 weeks of age, when she developed fever and vomiting and had a generalised tonic seizure while travelling in the United States. No other family members had a history of recent diarrhoeal illness. However, the patient had been exposed to possibly contaminated milk from local Saipan sources several days before her diarrhoeal illness. In addition, a pet turtle was kept by the family (outside the home). Diarrhoeal diseases were reported by the family to be a frequent cause of illness and death among infants in Saipan.

Received for publication 24 January 1980
On initial examination she appeared lethargic with a temperature of $104^{\circ} \mathrm{F}$, pulse $200 /$ minute, and respiration $60 /$ minute. She had a bulging fontanelle and generalised increased muscle tone and hyperreflexia. Initial laboratory evaluation showed a peripheral leucocytosis of $22000 / \mu \mathrm{l}\left(22.0 \times 10^{9} / 1\right)$ with $27 \%$ bands and $53 \%$ segmented. The cerebrospinal fluid had $5600 / \mu \mathrm{l}\left(5.6 \times 10^{9} / 1\right)$ white blood cells $(96 \%$ segmented neutrophils), protein 217 $\mathrm{mg} / 100 \mathrm{ml}(2 \cdot 17 \mathrm{~g} / \mathrm{l})$, glucose $4 \mathrm{mg} / 100 \mathrm{ml} \mathrm{(0.22}$ $\mathrm{mmol} / \mathrm{l})$ with a peripheral glucose of $151 \mathrm{mg} / 100 \mathrm{ml}$ $(8.38 \mathrm{mmol} / \mathrm{l})$ and bipolar Gram-negative rods were seen on the Gram stain. Cultures of blood and CSF yielded an organism that was called a nontypable Salmonella sp., later identified as $\boldsymbol{A}$. hinshawii by the Public Health Laboratories. The organism was found to be sensitive to ampicillin, chloramphenicol, carbenicillin, gentamicin, kanamycin, and gantrisin.

Hospital management included immediate administration of intravenous ampicillin at 400 $\mathrm{mg} / \mathrm{kg}$ per day in six divided doses, and intravenous chloramphenicol at $100 \mathrm{mg} / \mathrm{kg}$ per day in four divided doses. Fluids were restricted to threefourths of maintenance requirements, and intramuscular phenobarbital was begun for persistent minor motor seizures. She improved markedly during the first 6 hours and was afebrile and alert by day 3. As the organism was sensitive to ampicillin and chloramphenicol, therapy with chloramphenicol was discontinued after 24 hours, at which time a repeat lumbar puncture showed $100 / \mu \mathrm{l}\left(0 \cdot 1 \times 10^{9} / \mathrm{l}\right)$ white blood cells (91\% segmented neutrophils), protein $185 \mathrm{mg} / 100 \mathrm{ml}(1 \cdot 85 \mathrm{~g} / \mathrm{l})$, and glucose $22 \mathrm{mg} / 100 \mathrm{ml}(1.22 \mathrm{mmol} / \mathrm{l})$, and there was no 
growth on culture.

On the fourth day of her course, chloramphenicol was restarted at $100 \mathrm{mg} / \mathrm{kg}$ per day intravenously. Repeat lumbar puncture on transfer to Children's Hospital National Medical Center on day 5 showed $141 / \mu 1\left(0.14 \times 10^{9} / 1\right)$ white blood cells $(33 \%$ segmented neutrophils), glucose $40 \mathrm{mg} / 100 \mathrm{ml}$ $(2.22 \mathrm{mmol} / \mathrm{l})$, protein $148 \mathrm{mg} / 100 \mathrm{ml}(1.48 \mathrm{~g} / \mathrm{l})$, lactic acid $18 \mathrm{mg} / 100 \mathrm{ml}(1.99 \mathrm{mmol} / \mathrm{l})$, a negative limulus test and Gram stain, and a culture positive for the same species of Arizona. Stool cultures taken from the patient on day 5 of therapy showed no pathogens. Stool cultures obtained from all immediate members of the family were also negative. On day 9, five days after restarting chloramphenicol and with uninterrupted ampicillin therapy, repeat lumbar puncture was sterile with $48 / \mu 1(0.048 \times$ $\left.10^{9} / 1\right)$ white blood cells (all lymphocytes), glucose $46 \mathrm{mg} / 100 \mathrm{ml}(2.55 \mathrm{mmol} / \mathrm{l})$, protein $97 \mathrm{mg} / 100 \mathrm{ml}$ $(0.97 \mathrm{~g} / \mathrm{l})$, lactic acid $17 \mathrm{mg} / 100 \mathrm{ml}(1.89 \mathrm{mmol} / \mathrm{l})$, and limulus negative.

Her clinical course subsequent to transfer was notable for steady improvement in the level of activity, with no fever or seizures. After transfer she received an additional 21 days of intravenous ampicillin, $400 \mathrm{mg} / \mathrm{kg}$ per day in four divided doses, and intravenous chloramphenicol, $75 \mathrm{mg} / \mathrm{kg}$ per day in four divided doses. After 48 hours off antibiotics she remained afebrile and asymptomatic and had a spinal tap which showed $8 / \mu \mathrm{l}\left(0.008 \times 10^{9} / \mathrm{l}\right)$ white blood cells (all lymphocytes), glucose $42 \mathrm{mg} / 100 \mathrm{ml}$ $(2.33 \mathrm{mmol} / \mathrm{l})$, protein $46 \mathrm{mg} / 100 \mathrm{ml}(0.46 \mathrm{~g} / \mathrm{l})$, lactic acid $6 \mathrm{mg} / 100 \mathrm{ml}(0.67 \mathrm{mmol} / \mathrm{l})$, negative limulus and Gram stain, and no growth on culture. She was discharged in good condition.

On follow-up examination four weeks after discharge, the patient had remained asymptomatic, was gaining weight, and achieving developmental milestones normally. Neurological examination was completely normal and an electroencephalogram (EEG) was within normal limits for her age.

\section{Discussion}

Previously described cases of human disease caused by $A$. hinshawii are most notable for a high incidence of localised infection in immunocompromised hosts. ${ }^{1}$ The three cases reported in children included an age range of 2 to 7 years, all having an underlying disease such as sickle cell anaemia or Letterer-Siwe disease. Young infants, such as the one described here, may be considered immunocompromised hosts in terms of their susceptibility to bacterial meningitis. This is probably based on diminished barriers between bowel flora and bloodstream, increased meningeal permeability, ${ }^{34}$ and relatively poor opsonisation and leucocyte bactericidal activity, particularly against invasive encapsulated organisms. It appears that this case represents a relatively immunocompromised host's response to exposure to a pathogenic organism, which may be widespread in the South Pacific.

Arizona species are known to occur naturally in reptiles and poultry and possibly in many other animals. ${ }^{1}$ It is similar to Salmonella species in its capacity for producing an asymptomatic gastrointestinal carrier state in humans, ${ }^{5}$ a fact which further suggests that it is a fairly common food contaminant. It is also recognised that food sanitation techniques are considerably less advanced in developing countries. It is therefore highly probable that this patient's illness resulted from exposure to a contaminated food source.

In a review of salmonella meningitis, ${ }^{2}$ Rabinowitz and MacLeod observed a relatively poor overall outcome. And, in contrast to other forms of bacterial meningitis, a combination of chloramphenicol and ampicillin intravenously for three weeks provided optimal therapy. This case follows a similar pattern in the severity of its initial clinical manifestations and the relapse after early withdrawal of chloramphenicol. The reason for this apparent synergism between ampicillin and chloramphenicol is not known but may come from a further understanding of the infant's immune response to this group of organisms.

This case, however, differed from those reported by Rabinowitz in its favourable outcome. This may be due in part to early treatment with appropriate antibiotics and in part to adequate control of complications such as seizures and inappropriate ADH syndrome. Titzhardinge et al. ${ }^{6}$ also found a poor outcome with Gram-negative meningitis in neonates. They reported $58 \%$ mortality and $44 \%$ long-term morbidity, where survival and fever sequelae correlated significantly with a cerebrospinal fluid protein of $500 \mathrm{mg} / 100 \mathrm{ml}(5.0 \mathrm{mmol} / \mathrm{l})$. The findings of CSF protein at most of $217 \mathrm{mg} / 100 \mathrm{ml}(2 \cdot 17$ $\mathrm{g} / \mathrm{l})$, of normal neurological examination and developmental status, and normal EEG all suggest a favourable prognosis in this case. However, longterm follow-up, especially for hearing and speech, will be recommended for this child.

\section{References}

${ }^{1}$ Johnson R, Lutwick L, Huntley G, et al. Arizona $h$. infections: New cases, antimicrobial sensitivities, and literature review. Ann Int Med 1976;85:587-92.

${ }^{2}$ Rabinowitz S, MacLeod N. Salmonella meningitis: A report of three cases and review of the literature. Amer $J$ Dis Chil 1972:123:259-62.

${ }^{3}$ Black P, Kunz L, Swartz M. Salmonellosis-A review of some unusual aspects II. $N$ Eng J Med 1960;262:866-70. 
${ }^{4}$ Tirgin R, Dodge P. Bacterial meningitis: Newer concepts of pathophysiology and neurologic sequelae. Ped Clin of NA 1976;23:541-57.

${ }^{5}$ Lee R, Cross J, Irving G, et al. Surveillance of some infectious diseases among aircrew personnel in South East Asia. Av Space Envir Med 1975;46:1152-4.

6 Titzhardinge P, Kazemi M, Ramsay M, et al. Long term sequelae of neonatal meningitis. Dev Med Child Neurol $1974 ; 16: 3-10$.

Requests for reprints to: Dr I Brook, Infectious Disease and Clinical Microbiology Laboratory, Children's Hospital National Medical Center, 111 Michigan Avenue, NW, Washington, DC 20010, USA. 